\title{
OPTYMALIZACJA KSZTAŁTU ORAZ ROZMIESZCZENIA KANAŁÓW CHŁODZĄCYCH W LOPATKACH TURBIN GAZOWYCH
}

\begin{abstract}
W pracy przedstawiono wyniki obliczeń dotyczących problemu chłodzenia łopatek turbin gazowych. Sformułowane zostało zagadnienie odwrotne dotyczące rozmieszczenia kanałów chłodzących w istniejącej konstrukcji łopatki z punktu widzenia kryterium optymalizacyjnego. Jako kryterium optymalizacji przyjęta została stała temperatura na brzegu zewnętrznym łopatki równa $600 \mathrm{~K}$ i $650 \mathrm{~K}$. Obliczenia wykonane zostały dla łopatki Mark2 przy założeniu, że znany jest rozkład współczynnika przejmowania ciepła na brzegu zewnętrznym łopatki. Wyniki obliczeń pokazują, że rozmieszczenie kanałów chłodzących w tej łopatce nie jest prawidłowe z punktu widzenia rozpatrywanego kryterium optymalizacyjnego.
\end{abstract}

Słowa kluczowe: zagadnienia odwrotne, źródła pozorne

\section{Wprowadzenie}

Turbina gazowa jest podstawowym źródłem napędu lotniczego, a także ważnym elementem konwersji energii w układach energetycznych. Istotnym czynnikiem podnoszącym efektywność przemian energetycznych w układach $\mathrm{z}$ turbiną gazową jest temperatura spalin na wlocie turbiny. Podnoszenie tej temperatury wpływa na sprawność obiegu termodynamicznego oraz poziom mocy jednostkowej [1]. Wysoka temperatura spalin powoduje, że materiały, z których zrobione są łopatki muszą mieć określone własności termofizyczne, aby mogły pracować w takich temperaturach. W tym celu stosuje się między innymi powłoki ochronne, mające zabezpieczyć łopatkę przed niekorzystnym wpływem temperatury gazów spalinowych oraz systemy chłodzenia łopatek. Przeciwdziałanie warunkom termicznym panującym w elementach turbin gazowych polega m.in. na [2]:

1. zastosowaniu chłodzenia wewnętrznego oraz zewnętrznego (filmowego),

2. doborze materiałów na łopatkę oraz powłokę ochronną,

3. wyborze czynnika chłodzącego.

\footnotetext{
${ }^{1}$ Agnieszka Wróblewska, Politechnika Poznańska, pl. Marii Skłodowskiej-Curie 5, 60-965 Poznań, tel. 61665 2213, e-mail:agnieszka.wroblewska@ poznan.pl.
} 
Zastosowanie systemów chłodzenia łopatek turbin gazowych umożliwia osiągnięcie temperatury spalin znacznie przewyższającej ograniczenia materiałowe dla łopatek niechłodzonych. Powoduje również komplikacje, do których należą znaczne gradienty temperatur w łopatkach. Gradienty temperatur związane są z naprężeniami termicznymi, które mają wpływ na trwałość elementów turbin gazowych. Działania, które należy podjąć, aby zmniejszyć negatywne skutki chłodzenia łopatek sprowadzają się m.in. do zapewnienia równomierności chłodzenia oraz modelowania kanałów łopatek turbin gazowych [2]. Współcześnie można wyróżnić kilka systemów chłodzenia: konwekcyjne, filmowe, strumieniowe (uderzeniowe), transpiracyjne, które stosuje się w zależności od temperatury spalin [3].

Przedmiotem rozważań prezentowanych $w$ tym artykule jest optymalizacja kształtu oraz rozmieszczenia kanałów chłodzących w łopatkach turbin gazowych. Zagadnienie to jest bardzo ważne $\mathrm{z}$ technicznego punktu widzenia. Jako przykład można tu wymienić pozycje [4], [5]. Pierwsza z nich zajmuje się poszukiwaniem położenia punktowych źródeł ciepła w obszarze łopatki. Druga wykorzystuje algorytm genetyczny do ustalenia położenia kanałów chłodzących w istniejącej konstrukcji łopatki C3X z dziesięcioma kanałami chłodzącymi [6]. Tak postawione zagadnienia należą do klasy zagadnień odwrotnych, a używając podziału wprowadzonego w pracy [7], są to:

- zagadnienia określenia kształtu obszaru (kształtu oraz rozmieszczenia kanałów chłodzących łopatki),

- zagadnienia identyfikacji warunków brzegowych (np. rozkładu temperatury na ścianach kanałów chłodzących).

Zagadnienia odwrotne należą do klasy zagadnień źle postawionych w sensie Hadamarda [8], co oznacza m.in., że małe zaburzenia wielkości zadanych powodują duże błędy rozwiązania zagadnienia odwrotnego. Istnieje wiele metod rozwiązywania zagadnień odwrotnych, z których ważniejsze to regularyzacja Tichonowa [9], algorytmy iteracyjne [10] oraz algorytm svd (singular value decomposition) [11]. Algorytm, którego modyfikacja prezentowana jest w tej pracy bazuje na iteracyjnym rozwiązywaniu ciągu zagadnień bezpośrednich, został opisany $\mathrm{w}$ [12]. Jest rozwinięciem idei prezentowanej w [13] polegającej na zastąpieniu obszaru wielospójnego jakim jest łopatka turbiny gazowej z kanałami chłodzącymi, obszarem jednospójnym. W obszarach dołączonych (kanałach chłodzących) wstawione są nieznane źródła ciepła. Problem odwrotny polegający na wyznaczeniu temperatury oraz gęstości strumienia ciepła na ścianach kanałów chłodzących zostaje w ten sposób zastąpiony wyznaczeniem nieznanej funkcji źródła (source heat conduction problem - SHCP). Tak postawione zagadnienia odwrotne można znaleźć w pracach [14 - 18]. Do identyfikacji źródeł ciepła stosowana jest m.in. metoda rozwiązań podstawowych (MFS) z algorytmem svd [15], regularyzacja Tichonowa [17] lub algorytmy iteracyjne 
[14]. Zagadnienia odwrotne związane z wyznaczaniem nieznanej funkcji źródła mają wiele rozwiązań [19].

\section{Sformułowanie problemu}

Rozważmy równanie Poissona w obszarze $\Omega_{p}$ (rys.1) z nieznaną funkcją źródła w obszarach $\Omega_{i}$ (kanały chłodzące łopatki turbiny gazowej)

$$
\Delta T=f, \quad f=\left\{\begin{array}{lll}
f_{i} & \text { dla } & (x, y) \in \Omega_{i} \\
0 & \text { dla } & (x, y) \in \Omega
\end{array}, \quad \Omega_{p}=\Omega \cup \bigcup_{i} \Omega_{i}\right.
$$

ze znanym warunkiem brzegowym trzeciego rodzaju

$$
-\left.\lambda \frac{\partial T}{\partial n}\right|_{\Gamma_{z}}=\alpha_{z}\left(\left.T\right|_{\Gamma_{z}}-T_{p}\right)
$$

gdzie $\alpha_{z}$ - współczynnik przejmowania ciepła na powierzchni zewnętrznej łopatki, $T_{p}$ - temperatura płynu otaczającego łopatkę turbiny gazowej. Brakującą informacją potrzebną do wyznaczenia nieznanej funkcji źródła $f$ jest kryterium optymalizacyjne

$$
\min _{f} J[f]=\min _{f} \frac{1}{2} \int_{\Gamma_{z}}\left(T(f)-T_{o}\right)^{2} d s
$$

gdzie $T_{o}$ - zadana stała temperatura na zewnętrznym brzegu obszaru łopatki.

Tak postawione zagadnienie odwrotne jest równoważne zagadnieniu Cauchy'ego dla równania Laplace'a w obszarze wielospójnym $\Omega$ [12], w którym z warunku brzegowego (2) i kryterium optymalizacji (3) są wyznaczane temperatura i strumień ciepła na ścianach kanałów chłodzących.

Sprowadzenie rozwiązywania zagadnienia Cauchy'ego w obszarze wielospójnym do rozwiązywania zagadnienia Poissona w obszarze jednospójnym z nieznanymi funkcjami źródła w obszarach dołączonych pozwala na postawienie następującego zagadnienia odwrotnego, ważnego z technicznego punktu widzenia. Dla istniejącej konstrukcji łopatki turbiny gazowej, założonych warunków pracy oraz kryterium optymalizacyjnego, należy określić poprawność rozmieszczenia kanałów chłodzących w łopatce turbiny gazowej.

Dla istniejącej konstrukcji łopatki problem sprowadza się do znalezienia rozkładu mocy pozornych źródeł ciepła w kanałach chłodzących, przy czym wartości mocy źródeł otrzymane w wyniku rozwiązania zagadnienia odwrotnego nie powinny zmieniać znaku. Zmiana znaku funkcji źródła prowadzi do oscylacji rozwiązania zagadnienia odwrotnego. 


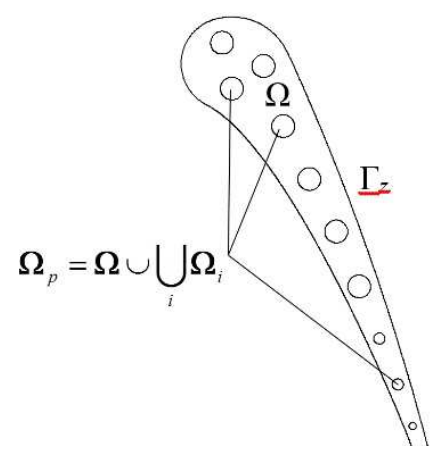

Rys. 1. Obszar łopatki turbiny gazowej Mark 2 z kanałami chłodzącymi [6]

Fig. 1. Region of the gas turbine blade Mark2 with cooling channels [6]

\section{Metoda rozwiązania zagadnienia odwrotnego}

Algorytm iteracyjny [12], który rozwiązuje równanie Poissona (1) z nieznaną funkcją źródła $f$, warunkiem brzegowym (2) i kryterium optymalizacji (3), po modyfikacji jest postaci:

krok 1. rozwiązanie równania Laplace'a

$$
\begin{array}{ll}
\Omega_{p}: & \Delta T^{m}=0 \\
\Gamma_{z}: & -\lambda \frac{\partial T^{m}}{\partial n}=\alpha_{z}\left(T^{m}-T_{p}\right)
\end{array}
$$

krok 2. rozwiązanie równania sprzężonego

$$
\begin{array}{ll}
\Omega_{p}: & \Delta p^{m}=0, \\
\Gamma_{z}: & \frac{\partial p^{m}}{\partial n}=-\frac{\alpha_{z}}{\lambda} p^{m}-T^{m}+T_{o} .
\end{array}
$$

krok 3. wyznaczenie funkcji poliharmonicznej $\Delta^{-k} p^{m}$

$$
\begin{aligned}
& \Omega_{p}: \quad w_{0}=p^{m} \\
& \text { for } j=1 \text { to } k \quad \Omega_{p}: \quad \Delta w_{j}=w_{j-1},
\end{aligned}
$$

$$
\Gamma_{z}: \quad w_{j}=0
$$

krok 4. Rozwiązanie równania Poissona

$$
\begin{aligned}
& \Omega_{p}: \quad \Delta u^{m}=q, \quad q=\left\{\begin{array}{ccc}
w_{k}, & \text { jesli } & (x, y) \in \Omega_{i} \\
0, & \text { jesli } & (x, y) \in \Omega
\end{array}\right. \\
& \Gamma_{z}: \frac{\partial u^{m}}{\partial n}=-\frac{\alpha_{z}}{\lambda} u^{m}
\end{aligned}
$$

krok 5. Wyznaczanie optymalnej wartości $\eta$ 


$$
\begin{aligned}
& \eta=\frac{\sum_{i} \int_{\Omega_{i}} p^{m}(-\Delta)^{-k} p^{m} d \omega}{\int_{\Gamma_{z}}\left(u^{m}\right)^{2} d s} \\
& \Omega: \quad T^{m+1}=T^{m}-\eta u^{m} \\
& \Omega_{i}: \quad f_{i}^{m+1}=f_{i}^{m}-\eta \Delta^{-k} p^{m}
\end{aligned}
$$

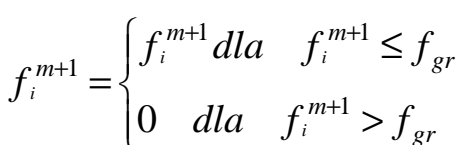

$$
\begin{aligned}
& \text { jeśli }\left|f_{i}^{m+1}-f_{i}^{m}\right|>\boldsymbol{\varepsilon} \text { wtedy } m=m+1 \text { idź do krok } 2 \text {. }
\end{aligned}
$$

Do wyznaczenia rozkładu temperatury oraz gęstości mocy źródeł ciepła w kolejnej iteracji potrzebne jest znalezienie rozkładu funkcji $p$ (krok 2) sprzężonej z $T$ oraz kolejnych funkcji $w_{j}, j=1,2, . ., k$, które służą do wyznaczenia funkcji $\Delta^{-k} p$ (krok 3). Funkcje $u, \Delta^{-k} p$ są przyrostami temperatury $T$ oraz gęstości mocy źródła $f$, które zmieniają się w procesie iteracji.

Algorytm iteracyjny rozwiązywania zagadnienia odwrotnego metodą źródeł pozornych opisany w pracy [12], przykład 1, dał poprawne rozkłady temperatury na brzegu wewnętrznym obszaru, ale przebieg funkcji źródła miał charakter oscylacyjny, rys.2. W cytowanej pracy, warunki brzegowe zostały wygenerowane dla pierścienia kołowego $\left(r_{0}<r<1\right)$ z funkcji analitycznej, która ma osobliwość w pobliżu brzegu wewnętrznego pierścienia $\left(a<r_{0}\right)$

$$
T(r, \varphi)=T_{c}+C \cdot \ln r+C \cdot \sum_{m=1}^{\infty} \frac{1}{2 m}\left[(a r)^{m}-\left(\frac{a}{r}\right)^{m}\right] \cos (m \varphi)
$$

Przykład został tak sparametryzowany $\left(C=0.5, a=0.4, T_{c}=0.9, r_{0}=0.5\right)$, że ciepło wpływa przez zewnętrzny brzeg do obszaru, a wpływa przez wewnętrzny brzeg. Otrzymany rozkład gęstości źródła w całym obszarze dołączonym (koło $r<0.5$ ) miał wartości różne od zera, które dodatkowo zmieniały znak, rys. 2.

Ponieważ rozwiązanie zagadnienia odwrotnego z nieznaną funkcją źródła jest niejednoznaczne, oznacza to, że dla tych samych warunków brzegowych (2) i kryterium optymalizacji (3) można otrzymać różne funkcje źródła. Ponadto ze względu na rozpatrywany proces fizyczny funkcja źródła nie powinna zmieniać znaku (płyn przepływający w kanale chłodzącym powinien odbierać ciepło wzdłuż całego brzegu kanału). Można zatem zmodyfikować działanie algorytmu z pracy [12] przez wyzerowanie w każdym kroku iteracji tych wartości źródła $f$, które będą większe od wartości granicznej $f_{g r}$. 

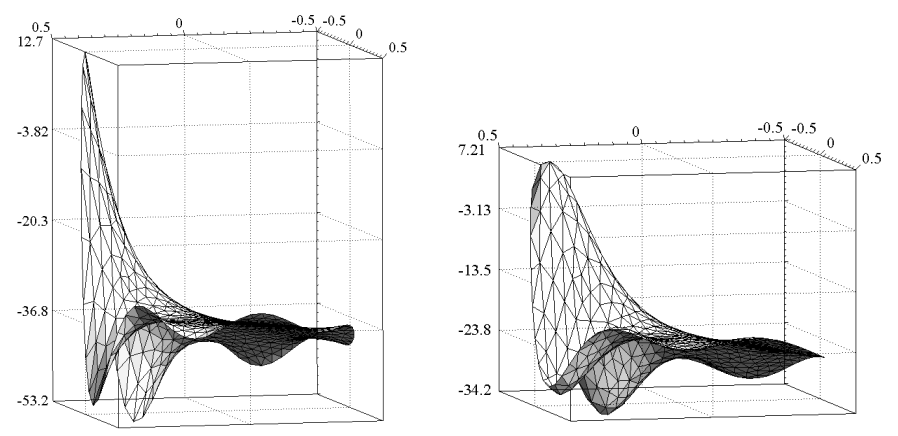

Rys. 2. Rozkłady gęstości mocy źródła w kole o promieniu $r_{0}=0.5$ dla parametru $k=0$ (z lewej) $\mathrm{i}$ $k=1$ (z prawej) [12]

Fig. 2. Distributions of power density of the source in the circle of the radius of $r_{0}=0.5$ for the parameter $k=0$ (left) and $k=1$ (right) [12]
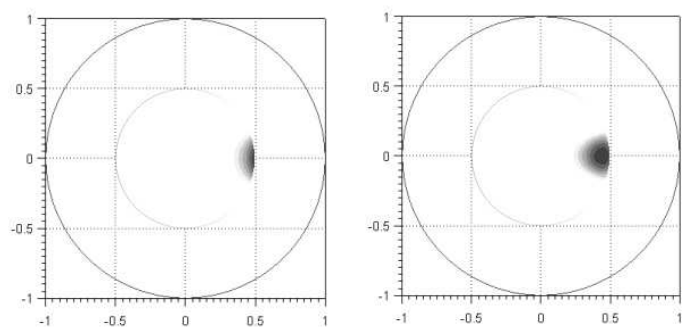

Rys. 3. Rozkłady gęstości mocy źródła w kole o promieniu $r_{0}=0.5$ dla parametru $k=0$ (z lewej) i $k=$ 1 (z prawej); algorytm zmodyfikowany $f_{g r}=0$

Fig. 3. Distributions of power density of the source in a circle of radius of $r_{0}=0.5$ for parameter $k=0$ (left) and $k=1$ (right); the modified algorithm $f_{g r}=0$

Wyniki obliczeń dla przykładu $1 \mathrm{z}$ pracy [12], otrzymane przy użyciu zmodyfikowanego algorytmu iteracyjnego przedstawia rys. 3. Działanie tego algorytmu po modyfikacji spowodowało eliminację obszarów, w których funkcja źródła dla oryginalnego algorytmu miała oscylacje, rys.2. Ostatecznie niezerowe wartości funkcji źródła pozostały w otoczeniu miejsca, gdzie analityczna funkcja źródła miała osobliwość.

$\mathrm{Z}$ analizy tych wyników wynika, że eliminacja obszarów w kanałach, w których zmienia się znak mocy źródła da odpowiedź dotyczącą prawidłowości rozmieszczenia kanałów chłodzących w łopatce turbiny gazowej. W przypadku prawidłowego położenia kanałów, oczekiwany rozkład gęstości mocy źródła powinien mieć najmniejszą wartość w centralnej części kanału.

\section{Obliczenia numeryczne}

Do obliczeń numerycznych przyjęty został profil łopatki Mark2 z dziesięcioma kanałami (rys. 4. z lewej), [6]. Z pracy tej przyjęte zostały: współczynnik 
przejmowania ciepła (rys. 4. z prawej), temperatura opływających łopatkę spalin $T_{p}=811 \mathrm{~K}$ oraz temperatura powietrza chłodzącego ściany kanałów (tablica 1.).

Tablica 1.Temperatura powietrza w kanałach chłodzących łopatki (numeracja kanałów pokazana na rys. 4. $\mathrm{z}$ lewej

Table 1. Temperature of air in the blade cooling channels (numeration of channels is shown inFig. 4. left)

\begin{tabular}{|l|c|c|c|c|c|c|c|c|c|c|}
\hline Kanał & $\mathbf{1}$ & $\mathbf{2}$ & $\mathbf{3}$ & $\mathbf{4}$ & $\mathbf{5}$ & $\mathbf{6}$ & $\mathbf{7}$ & $\mathbf{8}$ & $\mathbf{9}$ & $\mathbf{1 0}$ \\
\hline$T_{\text {air }}[\mathrm{K}]$ & 369 & 369 & 353 & 356 & 344 & 387 & 356 & 391 & 434 & 483 \\
\hline
\end{tabular}
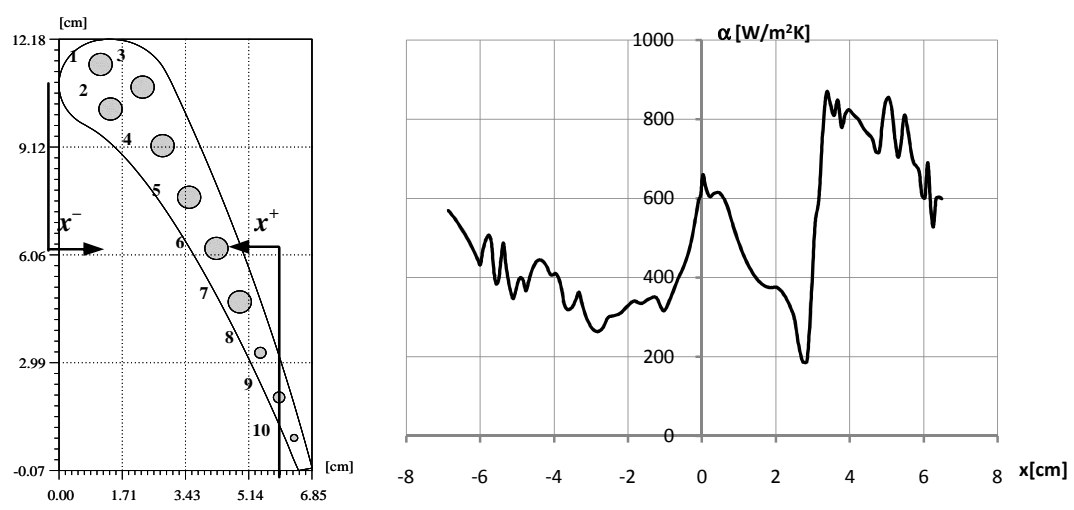

Rys. 4. Numeracja kanałów w łopatce Mark2 (z lewej); rozkład współczynnika przejmowania ciepła na brzegu zewnętrznym łopatki [6], RUN 154 (z prawej)

Fig. 4. Numeration of channels in the Mark2 blade (left); distribution of the heat transfer coefficient on the outer boundary of the blade [6], RUN 154 (right)

Obliczenia zostały wykonane metodą elementów brzegowych [6]. Parametry siatki do interpolacji liniowej warunków brzegowych na brzegu zewnętrznym łopatki oraz interpolacji liniowej gęstości mocy źródła w elemencie trójkątnym siatki przedstawione są w tablicy 2.

Tablica 2.Parametry siatki (liczba węzłów) elementów skończonych do interpolacji gęstości mocy źródła w kanałach oraz temperatury na ścianach kanałów łopatki Mark2 (liczba węzłów na brzegu zewnętrznym - 286)

Table 2. Parameters of mesh (number of nodes) of the finite-elements for interpolation of power density of the source in channels and parameters of the temperature on the walls of channels of the Mark2 blade (number of nodes on the outer boundary - 286)

\begin{tabular}{|c|c|c|c|c|c|c|c|c|c|c|c|}
\hline Nr kanału & $\mathbf{1}$ & $\mathbf{2}$ & $\mathbf{3}$ & $\mathbf{4}$ & $\mathbf{5}$ & $\mathbf{6}$ & $\mathbf{7}$ & $\mathbf{8}$ & $\mathbf{9}$ & $\mathbf{1 0}$ & razem \\
\hline Źródło & 113 & 101 & 121 & 101 & 105 & 105 & 117 & 29 & 33 & 33 & 858 \\
\hline Brzeg kanału & 32 & 32 & 32 & 32 & 32 & 32 & 32 & 16 & 16 & 16 & 272 \\
\hline
\end{tabular}




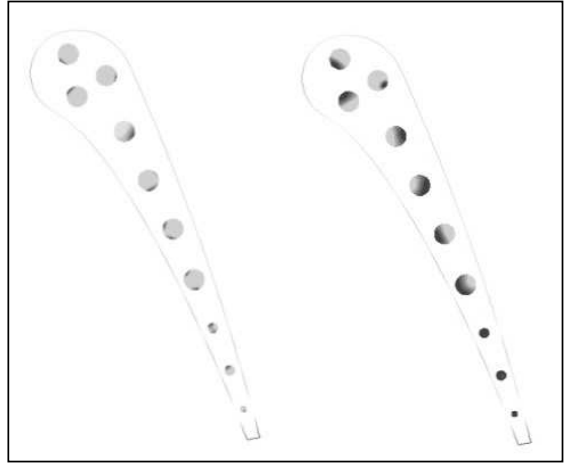

Rys.5. Rozkład mocy źródeł w kanalach lopatki Mark2 dla $f_{g r}=0, k=0(\mathrm{z}$ lewej) i $k=1$ (z prawej); $T_{\mathrm{o}}=600 \mathrm{~K}$

Fig. 5. Distribution of sources power in channels of the Mark blade for $f_{g r}=0, k$ $=0$ (left) and $k=1$ (right); $T_{\mathrm{o}}=600 \mathrm{~K}$

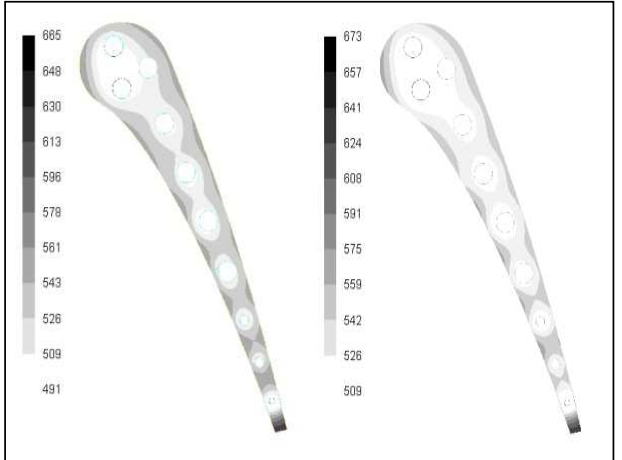

Rys. 6. Rozkład temperatury w łopatce Mark2 dla $f_{g r}=0, k=0$ (z lewej) i $k=1$ (z prawej); $T_{\mathrm{o}}=600 \mathrm{~K}$

Fig. 6. Distribution of temperature in the Mark2 blade for $f_{g r}=0, k=0$ (left) and $k=1$ (right); $T_{\mathrm{o}}=600 \mathrm{~K}$

Wyniki obliczeń dla temperatury $T_{o}=600 \mathrm{~K}$ pokazane są na rysunkach $5-8$, a dla temperatury $T_{o}=650 \mathrm{~K}$ na rysunkach $9-12$. Rys. 5. i 9. przedstawiają rozkład gęstości mocy źródeł w kanałach łopatki dla różnych parametrów $k(k=0$, 1) algorytmu i wskazują na kierunki przesunięcia kanałów w łopatce (ciemniejsza część rozkładu mocy źródła w kanałach). Obszary wyłączone z procesu chłodzenia oznaczone są kolorem jasnym). Jeśli zatem w kanale chłodzącym zmodyfikowany algorytm nie znajdzie obszarów kanału, w których funkcja źródła zmienia znak, to znaczy, że kanał chłodzący spełnia swoją funkcję w całym przekroju. Im mniejsza zmienność funkcji źródła, tym lepsze usytuowanie kanału w łopatce. Dla $k=1$ zmodyfikowany algorytm wyznaczył wartość funkcji źródła równą zeru w kanałach 8, 9 i 10.

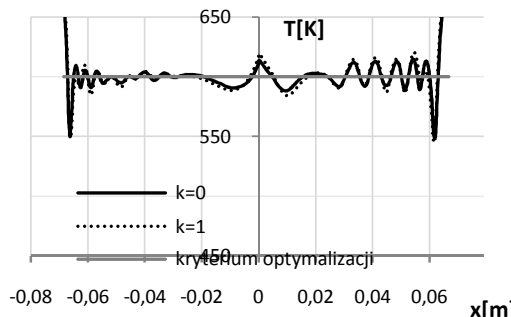

$\begin{array}{lllllllll}-0,08 & -0,06 & -0,04 & -0,02 & 0 & 0,02 & 0,04 & 0,06 & \mathbf{x}[\mathbf{m}]\end{array}$
Rys.7. Rozkład temperatury na brzegu zewnętrznym łopatki Mark2 dla $f_{g r}=0 ; k=0,1$; $T_{\mathrm{o}}=600 \mathrm{~K}$

Fig.7. Distribution of temperature on the outer boundary of the Mark2 blade for $f_{g r}=0 ; k=0$, $1 ; T_{\mathrm{o}}=600 \mathrm{~K}$ 


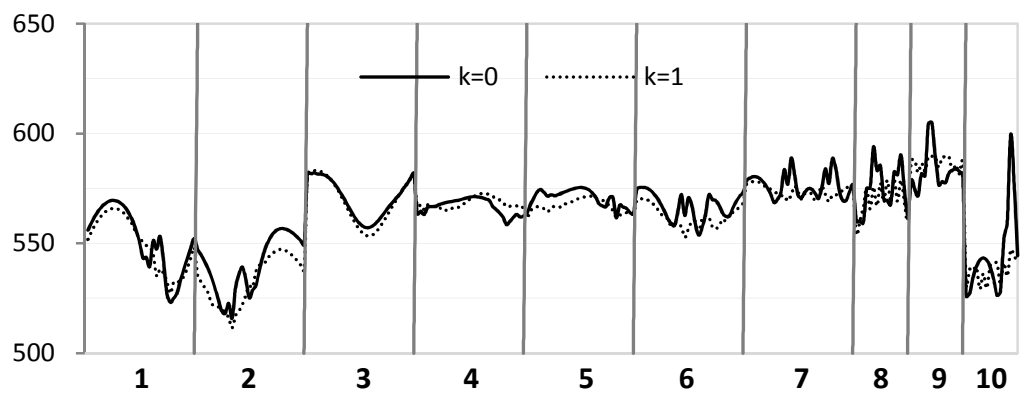

Rys.8. Rozkład temperatury w kanałach łopatki Mark2 dla $f_{g r}=0 ; k=0,1 ; T_{\mathrm{o}}=600 \mathrm{~K}$

Fig.8. Distribution of temperature in channels of the Mark2 blade for $f_{g r}=0 ; k=0,1 ; T_{\mathrm{o}}=600 \mathrm{~K}$

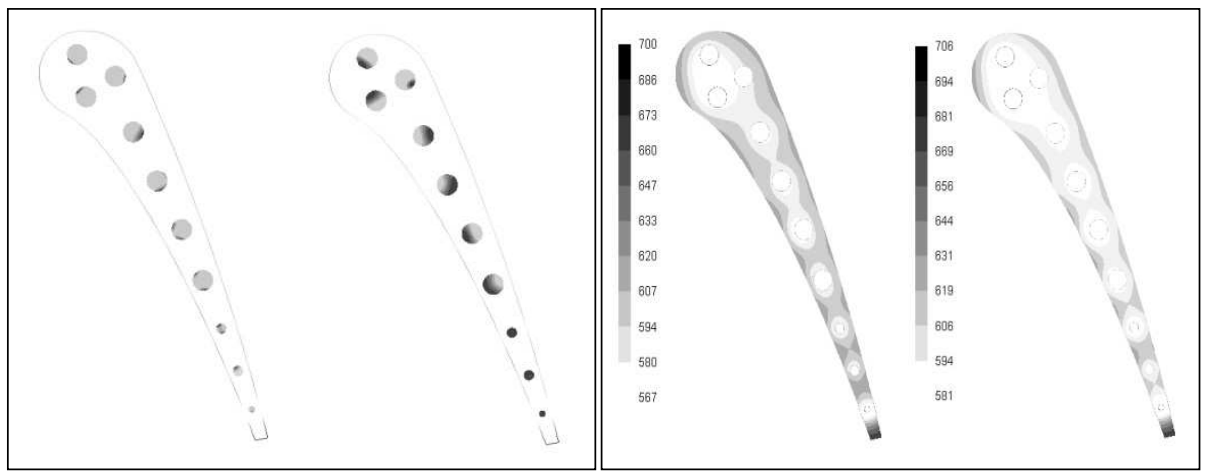

Rys.9. Rozkład mocy źródeł w kanałach Rys.10. Rozkład temperatury w łopatce łopatki Mark2 dla $f_{g r}=0, k=0$ (z lewej) i $k=$ Mark2 dla $f_{g r}=0, k=0$ (z lewej) i $k=1$ (z 1 (z prawej); $T_{\mathrm{o}}=650 \mathrm{~K}$ prawej); $T_{\mathrm{o}}=650 \mathrm{~K}$

Fig. 9. Distribution of sources power in Fig. 10. Distribution of temperature in the channels of the Mark blade for $f_{g r}=0, k=0$ Mark2 blade for $f_{g r}=0, k=0$ (left) and $k=$ left) and $k=1$ (right); $T_{\mathrm{o}}=650 \mathrm{~K}$ 1 (right); $T_{\mathrm{o}}=650 \mathrm{~K}$

Jednak aby ocenić, czy algorytm działa prawidłowo, potrzebna jest dodatkowa informacja związana z rozkładem temperatury na powierzchni zewnętrznej łopatki. Inaczej mówiąc jak daleko od założonej temperatury (kryterium optymalizacji) znajduje się otrzymany rozkład - rys. 7. i 11. Z rysunków tych wynika, że temperatura na powierzchni zewnętrznej łopatki w pobliżu kanałów 8, 9. i 10. silnie oscyluje, co znaczy, że w tym miejscu kanały o tym kształcie nie powinny się znajdować.

Warto zwrócić uwagę na rozkłady temperatury w kanałach łopatki pokazane na rys. 8. i 12. Rozkłady te nie oscylują, a temperatura ma fizyczne wartości. Jest to efekt regularyzacji rozwiązania zagadnienia odwrotnego otrzymany przez modyfikację pierwotnego algorytmu. Rezultaty z pracy [12] trzeba było 
uśredniać a potem dodatkowo rozwiązywać zagadnienie bezpośrednie dla uśrednionych wartości temperatury oraz strumienia ciepła w kanałach łopatki.

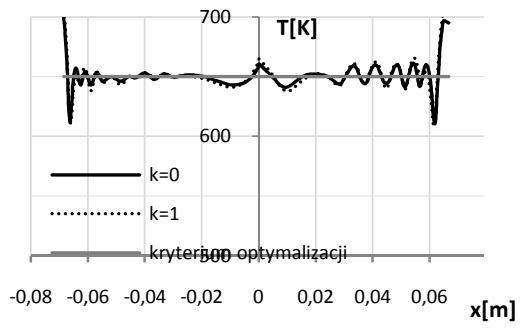

Rys.11. Rozkład temperatury na brzegu zewnętrznym łopatki Mark2 dla $f_{g r}=0 ; k=0,1$; $T_{\mathrm{o}}=650 \mathrm{~K}$

Fig.11. Distribution of temperature on the outer boundary of the Mark2 blade for $f_{g r}=0$; $k=0,1 ; T_{\mathrm{o}}=650 \mathrm{~K}$

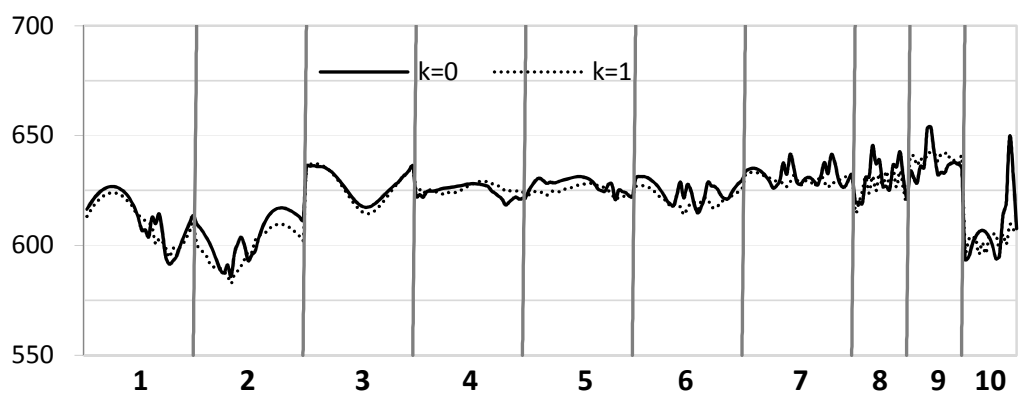

Rys.12. Rozkład temperatury w kanałach łopatki Mark2 dla $f_{g r}=0 ; k=0,1 ; T_{\mathrm{o}}=650 \mathrm{~K}$

Fig.12. Distribution of temperature in channels of the Mark2 blade for $f_{g r}=0 ; k=0,1 ; T_{\mathrm{o}}=650 \mathrm{~K}$

Rozkłady temperatur w łopatce przedstawione na rys. 6. i 10. wskazują na duże gradienty temperatur w zwężającej się części łopatki w kierunku krawędzi spływu. Spowodowane jest to nieprawidłowym kształtem kanałów chłodzących w tej części łopatki.

Obliczenia przeprowadzone dla różnych wartości kryterium optymalizacji, wskazują na podobieństwo rozkładów temperatur oraz gęstości mocy źródeł. Oznacza to, że można skonstruować system chłodzenia łopatek turbiny gazowej, który będzie spełniał kryterium optymalizacji $\left(T_{o}=\right.$ const $)$ w pewnym zakresie temperatury $T_{o}$, przy założeniu takiego samego współczynnika przejmowania ciepła na zewnętrznym brzegu łopatki.

\section{Podsumowanie}

Analiza wyników obliczeń numerycznych pokazuje, że algorytm iteracyjny wraz z zaproponowaną modyfikacją (polegającą na zerowaniu funkcji źródła w części kanałów, w których funkcja ta przekracza wartość graniczną $f_{g r}$ ), może być stosowany do rozwiązywana problemów związanych $\mathrm{z}$ rozmieszczeniem kanałów chłodzących w łopatkach turbin gazowych. 
Z obliczeń numerycznych wynika, że:

- kanały chłodzące powinny być przesunięte w obszarze łopatki w sposób pokazany na rys. 5. i 9. (kierunek przesunięcia wskazuje ciemniejszy fragment kanału),

- rozkład temperatury na powierzchni zewnętrznej łopatki w stosunku do kryterium optymalizacji stanowi dodatkową informację, która służy do oceny położenia kanałów chłodzących. Dla analizowanego procesu chłodzenia łopatki Mark2, rys. 4. (z lewej), stosowanie kanałów o przekroju kołowym w zwężającej się części łopatki, powoduje oscylacje temperatury na zewnętrznym brzegu łopatki, a co z tym związane - duże gradienty temperatur w tej części łopatki,

- dla określonej wartości współczynnika przejmowania ciepła na powierzchni zewnętrznej łopatki istnieje duże podobieństwo rozkładu temperatury w łopatce oraz gęstości źródeł ciepła w kanałach chłodzących dla różnych wartości kryterium optymalizacji $T_{o}=600 \mathrm{~K}$ i $T_{o}=650 \mathrm{~K}$,

- wyznaczone na podstawie rozkładu źródeł pozornych w kanałach, rozkłady temperatury na ścianach kanałów nie wykazują silnych oscylacji, typowych dla rozwiązania zagadnienia odwrotnego.

\section{Literatura}

[1] Lakshminarayana B.: Fluid dynamics and heat transfer of turbomachinery, Wiley \& Sons Inc., 1996.

[2] Bunker R.S.: Gas turbine heat transfer: 10 remaining hot gas path challenges, ASME Paper GT2006-90002, 2006.

[3] Brenberg J.: Turbulence modelling for internal cooling of gas-turbine blades, PhD Thesis, Department of thermo and fluid dynamics, Chalmers University of Technology, Goeteborg 2002.

[4] V. Wolfersdorf J., Achermann E., Weigand B.: Shape optimization of cooling channels using genetic algorithms, J. Heat Transfer, 119 (1997) 380-388.

[5] Nowak G., Wróblewski W., Chmielniak T.: Optimization of cooling passages within a turbine vane, Proc. ASME TurboExpo 2005, Paper GT 2005-68552, pp. 1-8.

[6] Hylton L.D., Mihelc M.S., Turner E.R., Nealy D.A., York R.E.: Analytical and experimental evaluation of the heat transfer distribution over the surfaces of turbine vanes, NASA CR-168015 DDA EDR 11209, 1983.

[7] Dulikravich G.S., Martin T.J., Dennis B.H., Multidisciplinary inverse problems. 3rd Int. Conf. Inverse Problems in Engineering, Port Ludlow, USA, 1999.

[8] Hadamard J.: Sur les problèmes aux dérivées partielles et leur signification physique, Princeton University Bulletin 1902, pp. 49-52.

[9] Alifanov O.M.: Inverse Problems, Moscow, 1988.

[10] Beck J.V., Blackwell B., Clair C.R.: Inverse heat conduction Ill-posed problems, New York, 1985. 
[11] Louis A.K.: Inverse und schlecht gestellte Probleme, Teubner Studienbücher: Mathematik, Stuttgart 1989.

[12] Frąckowiak A., Botkin N.D., Ciałkowski M., Hoffmann K-H.: Iterative algorithm for solving the heat conduction inverse problems with the method of fictitious sources, in Science and Engineering, 2014.

[13] Frąckowiak A., v. Wolfersdorf J., Ciałkowski M.: Solution of the inverse heat conduction problem described by the Poisson equation for a cooled gas-turbine blade, Int. J. Heat Mass Transfer, 54 (2011) 1236-1243.

[14] Cannon J.R., Duchateau P.: Structural identification of an unknown source term in heat equation, Inverse Problems, 14 (1998) 535-551.

[15] Jin B., Marin L.: The method of fundamental solutions for inverse source problems associated with the steady-state heat conduction, Int. J. Numerical Methods Eng., 69 (2007) 1570-1589.

[16] Ling L., Yamamoto M., Hon Y.C., Takeuchi T.: Identification of source locations in two-dimensional heat equations, Inverse Problems, 22 (2006) 1289-1305.

[17] Yan L., Fu C.-L., Yang F-L.: The method of fundamental solutions for the inverse heat source problem, Eng. Analysis Boundary Elements, 32 (2008) 216-222.

[18] Yang C-Y.: The determination of two heat source in an inverse heat conduction problem, Int. J. Heat Mass Transfer, 42 (1999) 345-356.

[19] Alves C.J.S., Colaço M.J., Leitão V.M.A., Martins N.F.M., Orlande H.R.B., Roberty N.C.: Recovering the source term in a linear diffusion problem by the method of fundamental solutions, Inverse Problems Sci. Eng., 16 (2010)1005-1021.

\title{
OPTIMIZATION OF SHAPE AND ARRANGEMENT OF COOLING CHANNELS IN GAS TURBINE BLADES
}

\begin{abstract}
S u m m a r y
In this paper, the results of calculations concerning the problem of cooling the gas turbine blades were presented. The inverse problem from the optimization criterion point of view for the arrangement of cooling channels in already-existing blade construction was formulated. Constant temperature on the outer edge of the blade equals to $600 \mathrm{~K}$ and $650 \mathrm{~K}$ was assumed as the optimization criterion. Calculations were made for the Mark2 blade, assuming that the distribution of the heat transfer coefficient on the outer edge of the blade was known. Results of calculation show that the arrangement of cooling channels in this blade is not correct from the optimization criterion point of view.
\end{abstract}

Keywords: inverse problems, fictitious sources

DOI: $10.7862 / \mathrm{rm} .2014 .14$

Otrzymano/received: 15.05 .2014

Zaakceptowano/accepted: 27.05.2014 